\title{
Optimization of Transport Logistics for Forest Biomass
}

\author{
Miloš Gejdoš \\ Technical University in Zvolen \\ Faculty of Forestry \\ Department of Forest Harvesting, Logistics \\ and Ameliorations \\ Slovak Republic \\ e-mail: gejdos@tuzvo.sk

\section{Zdeněk Hřebíček \\ Institute of Technology and Business in České Budějovice \\ Faculty of Technology, Department of \\ Transport and Logistics, Czech Republic}

\author{
| Tomáš Gergel' \\ National Forest Centre in Zvolen \\ Slovak Republic \\ e-mail: tomasgergel@azet.sk

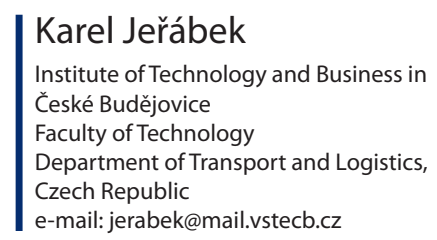

DOI 10.17818/NM/2018/4SI.15

UDK 656.01:604.4

Preliminary communication

Paper accepted: 28. 8. 2018.

\begin{abstract}
Summary
The Use of renewable resources on the basis of forest biomass is gradually becoming an international issue. The conditions for the optimal use include solving several technical, technological, economic and environmental problems. The contribution is aimed at solving a role model of optimization of forest biomass transport in the conditions of the School forestry enterprise of the Technical University in Zvolen. The solution is based on the algorithm-based working software the MODI mathematical methods. For the purposes of optimization, the following criteria have been selected: time consumption per $1 \mathrm{~m} 3$, cost per $1 \mathrm{~m} 3$ and fuel consumption per $1 \mathrm{~m} 3$. In total, $5995 \mathrm{~m} 3$ of forest biomass is to be transported. Regarding the first criterion, the total optimal solution is $809.62 \mathrm{~h}$, for the second criterion, the optimal value is $8871.15 €$ and for the third one it is $1.43 \mathrm{I} . \mathrm{m}-3$. The evaluated criteria are a partial solution of the transport problem optimization. What is important are also the links to technological background, anthropometric parameters of service and international trade, and connection to water transport in the case of REALIZACE OBCHODU with intercontinental trade partners.
\end{abstract}

\author{
KEY WORDS \\ forest biomass \\ transportation technologies \\ logistics \\ optimization
}

\section{INTRODUCTION}

The Use of forest biomass based renewable energy resources has recently become increasingly important. It has become an international issue, as the wood raw material is one of the few renewable raw materials for energy use. However, the optimal use of available forest biomass requires dealing with a number of mutually correlated technical, technological, economic, environmental and logistic problems, linked by conditionality and thus creating a narrow set of optimal technological solutions ranging from the extraction to final processing of biomass [1]. In the contribution, the authors focus on the example of optimal decision-making based on the distribution model. It is so-called classic transport problem pointing to the essential issues of the need for optimizing the variants.

In logistic system, cost calculation plays a significant role in optimizing specific activities, where the relevant effective solution is considered to be the one with the minimum implementation costs [2-4]. The scheme of the transport and logistics problem of transporting biomass in forestry can be briefly described as follows: There are suppliers who are able to supply certain amount of goods. A typical supplier is a collecting point and the goods are forest biomass. On the other side, there are customers who want to take a specific amount of biomass. Other known facts are the mutual conditions of the goods transportation from a particular supplier to a particular customer. The conditions imply costs, time, consumption of materials etc. The transport relationship between the supplier and the customer, identified and quantified by various indicators, is the evaluation of the transport route. If the suppliers' capacity and customers' demand are the same, the transport problem is balanced. However, this occurs rarely.

Classic transport problem is typically described by means of cost component as follows: The assumption is that the suppliers' capacity equals to the customers' requirements. It is necessary to decide which supplier should supply the customers in order to have the lowest overall freight costs [5]. The aim of the contribution is to solve the model example of the forest biomass transport, which optimizes the transport relations on the basis of the known algorithm of the MODI mathematical methods [6-8].

\section{METHODOLOGY}

The model example of forest biomass transport optimization was solved using the "LESDOP" software which optimizes the transport relations based on the known algorithm of the MODI mathematical method. The program assumes at least basic knowledge of the problem and the general knowledge of the 
algorithm of the calculation. These assumptions are necessary for understanding the effect of the resulting optimized outputs. The program works with a matrix with $\mathrm{M}$ number of rows and $\mathrm{N}$ number of columns (max. $\mathrm{M}=20, \mathrm{~N}=20$ ). After creating the transport relations matrix, the resulting matrices of the individual iterations are calculated with the quantification of the target function until the final optimal solution is found. As an input for the model example, the data from the School forestry enterprise of the Technical University in Zvolen were used:

- The Forest administration has 5 collecting points (suppliers): Lúky - $D_{1}$; Podjavor $-D_{2}$; Dúbravy $-D_{3}$; Mláčik $-D_{4}$; Lopaty $-D_{5}$

- There are 4 collection vehicles available:T $815-\mathrm{O}_{1}$; Iveco1 $\mathrm{O}_{2}$; Iveco2 $-\mathrm{O}_{3}$; Scania $-\mathrm{O}_{4}$.

- the wood is transported to the customer from the individual D distances: $D_{1}-24 \mathrm{~km} ; \mathrm{D}_{2}-18 \mathrm{~km} ; \mathrm{D}_{3}-35 \mathrm{~km} ; \mathrm{D}_{4}-41 \mathrm{~km}$; $\mathrm{D}_{5}-13 \mathrm{~km}$.

- at individual collecting points there are available the following volumes of biomass intended for energy use: $D_{1}-1050 \mathrm{~m}^{3} ; \mathrm{D}_{2}$ $-1400 m^{3} ; D_{3}-1250 m^{3} ; D_{4}-963 m^{3} ; D_{5}-1332 m^{3}$.

- loading capacity in $\mathrm{m}^{3}$ is as follows: $\mathrm{O}_{1}-10 \mathrm{~m}^{3} ; \mathrm{O}_{2}-14 \mathrm{~m}^{3}$; $\mathrm{O}_{3}-17 \mathrm{~m}^{3} ; \mathrm{O}_{4}-28 \mathrm{~m}^{3}$.

- transport requirements for the individual SOUPRAVY in $\mathrm{m}^{3}$ are as follows: $\mathrm{O}_{1}-870 \mathrm{~m}^{3} ; \mathrm{O}_{2}-1610 \mathrm{~m}^{3} ; \mathrm{O}_{3}-1688 \mathrm{~m}^{3} ; \mathrm{O}_{4}-$ $1827 \mathrm{~m}^{3}$.

- direct costs of $1 \mathrm{~h}$ operation are: $\mathrm{O}_{1}-8,62 € ; \mathrm{O}_{2}-9,2 € ; \mathrm{O}_{3}-$ $11,6 € ; \mathrm{O}_{4}-13,2 €$.

Other production and technical conditions are: average circumference of a tree trunk is $0.73 \mathrm{~m}^{3}$, the service consists of 2 workers, it is the summer period, the vehicles use asphalt roads with good surface and under normal conditions. The gradient of the road is $2-6 \%$. Wood is piled up using a grapple loader or front loader.

The aim is to optimize the transport of forest biomass to the processor while achieving the shortest time possible necessary for transport of $1 \mathrm{~m}^{3}$ of biomass or the lowest costs of transporting $1 \mathrm{~m}^{3}$ of biomass or ensuring the lowest fuel consumption per one fully loaded vehicle turn. Naturally defined objectives are not the only potentially declarable objectives in this field. As a task, a whole range of other indicators could be defined that more or less affect this process.

\section{RESULTS}

First of all, it was necessary to determine the time required per transport of $1 \mathrm{~m}^{3}$ of biomass for wood removal from each collecting point (D) and for each vehicle - collection vehicle (O). We will gain in total $5 \times 4-20$ data. The data were obtained from the performance standards [9].

Based on the time required per $1 \mathrm{~m}^{3}$ and costs of 1 hour of operation of vehicles, the transport costs per $1 \mathrm{~m}^{3}$ will be determined (20 data).

Based on the fuel consumption standards, consumption per $1 \mathrm{~m}^{3}$ for each collecting point and each vehicle will be identified. Those will be calculated for a fully loaded vehicle. Again, we will have a set of 20 data. For each task, a matrix with 4 rows and 5 columns can be created, where the data on the time required, costs or fuel consumption will be on the intersections of rows and columns based on the selected task. The data on the intersections represent the valuation of the transport relation in concrete units $(h, €, I)$. For the assigned model task, the individual data were calculated as showed in Table $1-3$.

The optimal solution was identified using the iterative method, i.e. searching for a better solution until the optimal one is found. The solution consists in assigning an appropriate amount of wood to individual routes (cells) so that the sum of the products of the transported volume of wood and the valuation is as low as possible (see Table 1 , Table 2 , Table 3 ). The sum of the products is a target function $(Z)$. When optimizing the time required per $1 \mathrm{~m}^{3}$, the optimal solution was found after 6 iterations, where the $Z$ values were from $981.43 \mathrm{~h}$ until the final optimal solution with the $Z$ value of $809.62 \mathrm{~h}$. The lowest consumption of time per $1 \mathrm{~m}^{3}$ will be achieved if the wood is transported via chosen routes, that is, from the designated collecting point, using the appropriate vehicle and at the calculated volume. The optimal consumption of time per $1 \mathrm{~m}^{3}$ will be $809.62 \mathrm{~h}: 5995 \mathrm{~m}^{3}=0.135 \mathrm{~h} \cdot \mathrm{m}^{-3}$.

Table 1 Input data for time consumption optimization per $1 \mathrm{~m}^{3}$

\begin{tabular}{|c|l|l|l|l|l|l|}
\hline $\mathrm{O} / \mathrm{D}$ & \multicolumn{1}{|c|}{$\mathrm{D}_{1}$} & \multicolumn{1}{|c|}{$\mathrm{D}_{2}$} & \multicolumn{1}{|c|}{$\mathrm{D}_{3}$} & \multicolumn{1}{c|}{$\mathrm{D}_{4}$} & \multicolumn{1}{c|}{$\mathrm{D}_{5}$} & Req. O \\
\hline $\mathrm{O}_{1}$ & 0.25 & 0.21 & 0.33 & 0.37 & 0.17870 & 870 \\
\hline $\mathrm{O}_{2}$ & 0.14 & 0.111148 & 0.18 & 0.20 & 0.09462 & 1610 \\
\hline $\mathrm{O}_{3}$ & 0.141050 & 0.12252 & 0.18386 & 0.19 & 0.11 & 1688 \\
\hline $\mathrm{O}_{4}$ & 0.11 & 0.10 & 0.13864 & 0.14963 & 0.09 & 1827 \\
\hline Capacity D & 1050 & 1400 & 1250 & 963 & 1332 & 5995 \\
\hline & & & & & \multicolumn{2}{c|}{$\mathrm{Z}_{\text {opt }}=809.62 \mathrm{~h}$} \\
\hline
\end{tabular}

Source: authors

Table 2 Input data for cost optimizing minimizing/ in $€$ per $1 \mathrm{~m}^{3}$

\begin{tabular}{|c|l|l|l|l|l|l|}
\hline O/D & \multicolumn{1}{|c|}{$\mathrm{D}_{1}$} & \multicolumn{1}{|c|}{$\mathrm{D}_{2}$} & \multicolumn{1}{|c|}{$\mathrm{D}_{3}$} & \multicolumn{1}{|c|}{$\mathrm{D}_{4}$} & \multicolumn{1}{|c|}{$\mathrm{D}_{5}$} & \multicolumn{1}{c|}{ Req. O } \\
\hline $\mathrm{O}_{1}$ & 2.155 & 1.810 & 2.845 & 3.189 & 1.465870 & 870 \\
\hline $\mathrm{O}_{2}$ & 1.288 & 1.012762 & 1.6561250 & 1.84 & 0.828462 & 1610 \\
\hline $\mathrm{O}_{3}$ & 1.6241050 & 1.392638 & 2.09 & 2.204 & 1.276 & 1688 \\
\hline $\mathrm{O}_{4}$ & 1.452 & 1.32 & 1.716 & 1.848963 & 1.188 & 1827 \\
\hline Capacity D & 1050 & 1400 & 1250 & 963 & 1332 & 5995 \\
\hline & & & & \multicolumn{2}{|c|}{$\mathrm{Z}_{\text {opt }}=8871.15 €$} \\
\hline
\end{tabular}

Source: authors 
Table 3 Input data for optimizing /minimizing/ the fuel consumption in I per one turn

\begin{tabular}{|c|l|l|l|l|l|l|}
\hline $\mathrm{O} / \mathrm{D}$ & \multicolumn{1}{|c|}{$\mathrm{D}_{1}$} & \multicolumn{1}{|c|}{$\mathrm{D}_{2}$} & \multicolumn{1}{|c|}{$\mathrm{D}_{3}$} & \multicolumn{1}{c|}{$\mathrm{D}_{4}$} & \multicolumn{1}{c|}{$\mathrm{D}_{5}$} & \multicolumn{1}{|c|}{ Req. O } \\
\hline $\mathrm{O}_{1}$ & 15 & 14 & 23 & 24870 & 9 & 870 \\
\hline $\mathrm{O}_{2}$ & 21 & 17267 & 271250 & 3193 & 14 & 1610 \\
\hline $\mathrm{O}_{3}$ & 241050 & 20638 & 32 & 36 & 16 & 1688 \\
\hline $\mathrm{O}_{4}$ & 31 & 26495 & 39 & 44 & 221332 & 1827 \\
\hline Capacity D & 1050 & 1400 & 1250 & 963 & 1332 & 5995 \\
\hline
\end{tabular}

Source: authors

When determining the minimum costs of $1 \mathrm{~m}^{3}$, the optimal solution was found in the 7th iteration. $8871.15 €: 5995 \mathrm{~m}^{3}=$ $1.48 € . \mathrm{m}^{-3}$

When optimizing fuel consumption, a more complex way of calculation of fuel consumption per one turn of a fully loaded vehicle was chosen. The value of target function $\left(Z_{\text {opt }}\right)$ has a clear information value, but represents only notional amount of fuel consumed. The actual consumption in litres will be calculated if the transported volume and consumption per one turn is converted/allocated per tonnage of the vehicle.

$Z_{\text {opt }}=[/ 870: 10 /$. 24] $+[/ 267: 14 /$. 17] $+[/ 1250: 14 /$. 27] + $[/ 1050: 17 / .24]+[/ 638: 17 / .20]+[/ 495: 28 / .26]+[/ 1332: 28] .22]$ $=8561.86 \mathrm{I}$.

The fuel consumption per $1 \mathrm{~m}^{3}$ will be $8561.86: 5995 \mathrm{~m}^{3}$ $=1.43 \mathrm{I} \mathrm{m}^{-3}$. For one task, 3 alternatives of valuation have been formulated and optimized (time, costs, fuel consumption). Three possible ways of transporting the given volume of biomass using the given vehicles were obtained. The final decision for a particular solution should be based on ensuring the priorities.

The choice of the optimal transport option criterion should be in line with the current needs of the operation. Besides the evaluated factor, logistics is influenced by many other factors that can have either seasonal or accidental character (forest road network density, season of the year, type of extraction etc.)

The road transport sector is one of the most risky ones in terms of number of fatal accidents at work. However, in the forestry sector, the production phase in timber extraction and transport process is much more risky. In terms of work accidents, this phase of the extraction and transport process is the least risky [10]. Nevertheless, when optimizing the transport of wood, even this factor must be taken into consideration. It is the time constraints and workload of the operational staff of the vehicles that can cause an increased risk of work accidents. In terms of days of the week, the most risky one seems to be Tuesday [11]. Taking into account the planned time of ODVOZ and consumption of time per $1 \mathrm{~m}^{3}$, this parameter should also be allowed for.

In the broader context, it is also necessary to consider anthropometric and ergonomic parameters of the individual vehicles as well as the workers. In this respect, one of the most important parameters are the dimension/ size of human feet, which showed the highest increase over the last 20 years [12]

\section{CONCLUSION}

The forest biomass transported within the integrated technology represents the most promising option of producing alternative energy compared to fossil fuels [1], [13]. In the future, in terms of optimizing raw material supply, the most important factors for energy performance will be time and transport distance [14].
Transport distance is also very important in assessing economic efficiency of using biomass from less valuable forests, or mass thinner than $7 \mathrm{~cm}$ [15]. However, for creating any optimization models, the input variables are important: the means of transport available (their capacity, performance, fuel consumption) and the transport options realizable. The transport by means of collection vehicles requires the appropriate in forest areas on hardened forest paths [16-21].

In our model example of optimizing the forest biomass transport, time constraints, costs per $1 \mathrm{~m}^{3}$ and time consumption were chosen as the main optimization criteria. For the management of forestry companies, these 3 criteria are the most important ones to be taken into account when choosing the optimal solution of transport and logistics problems [22], [23]. When choosing the optimal alternative, other optimization factors can play a part, such as the quality of the work carried out and the damage caused in relation to the service parameter. Another criterion can be the link to transport nodes and another type of transport, e.g. by sea, which is often used for exporting luxurious assortments of raw wood or wood-based biofuel to continental markets in accordance with the introduction of the so-called green logistics [24], [25].

With regard to the results of the model solution of optimization of forest biomass transport logistics in concrete conditions, it may be stated that the MODI mathematical methods areapplicable for solving transport problems. These methods can be used not only in road transport, but also in other types of transport used for transporting biomass and wood-based biofuel (especially rail or sea transport).

\section{ACKNOWLEDGEMENT}

The research described in this paper was financed jointly by the: APVV-16-0297 Updating of anthropometric database of Slovak population.

\section{REFERENCES}

[1] Messingerová, V., Sačkov, I., Vyskoková, Z. Logistika pre využívanie energie $z$ lesnej biomasy [Logistics for energy use from forest Biomass] Technical University in Zvolen, 2011, Scientific monograph. ISBN 978-80-228-2247-3.

[2] Yan, Q. Y., Zhang, Q. The Optimization of Transportation Costs in Logistics Enterprises with Time-Window Constraints. Discrete Dynamics In Nature and Society, 2015, Article No. 365367. https://doi.org/10.1155/2015/365367

[3] Rosová, A. Logistické náklady podniku [Logistics costs of the enterprise]. Acta Montanistica Slovaca, 2007, Vol. 12, No. 2, pp. 121-127. ISSN 1335-1788.

[4] Kampf, R., Lorincová, S., Hitka, M., Caha, Z. The application of ABC analysis to inventories in the automatic industry utilizing the cost saving effect. Nase more, 2016, Vol. 63, No 3, 2016, pp. 120-125. https://doi.org/10.17818/ NM/2016/SI8

[5] Lukáč, T. Lesná doprava [Forest transport], Technical University in Zvolen, Study textbook, 1990, 142 p. ISBN 80-228-0064-3.

[6] Dhanasekar, S., Hariharan, S., Sekar, P. Fuzzy Hungarian MODI Algorithm to Solve Fully Fuzzy Transportation Problems. International Journal of Fuzzy Systems, 2017, Vol. 19, No 5, pp. 1479-1491. https://doi.org/10.1007/s40815016-0251-4 
[7] Farheen, Z., Umamaheswari, T. S., Devi, M. T. Post optimal analysis for transportation problem, International Journal of Agricultural and Statistical Sciences, 2009, Vol. 5, No 2, pp. 531-535. ISSN 0973-1903.

[8] Arbogast, T., Huang, C. S. A fully mass and volume conserving implementation of a characteristic method for transport problems. Siam Journal of Scientific Computing, 2006, Vol. 28, No 6, pp. 2001-2022. https://doi. org/10.1137/040621077

[9] Výkonové normy v odvoze dreva [Output standards in wood transport]. Ministry of agriculture and Rural development of the Slovak republic, 1989, $34 \mathrm{p}$.

[10] Vlčková, M. Analýza vývoja pracovných úrazov a chorôb z povolania vo vybraných lesníckych subjektoch SR [Development analysis of work accidents and occupational diseases in selected Slovakian forestry subjects], Dissertation thesis, 149 p. Technical University in Zvolen, 2014.

[11] Gejdoš, M. Vlčková, M. Analysis of work accidents in timber transport in Slovakia. In: MATEC Web of Conferences, 2017, Vol. 134, Article No. 00014 https://doi.org/10.1051/matecconf/201713400014

[12] Hitka, M., Mračková, E., Sedmák, R. Changes of anthropometric characteristics of the adult population in Slovakia and their influence on material sources and work safety. Advanced Material Research, 2014, Vol. 1001, pp. 401-406. https://doi.org/10.4028/www.scientific.net/AMR.1001.401

[13] Liu, W.Y., Lin, C.C., Yeh, T.L. Supply chain optimization of forest biomass electricity and bioethanol coproduction. Energy, 2017, Vol. 139, pp. 630-645. https://doi.org/10.1016/j.energy.2017.08.018

[14] Teixeira, T. R. et al. Forest biomass power plant installation scenarios. Biomass \& Bioenergy, 2018, Vol. 108, pp. 35-47. https://doi.org/10.1016/j. biombioe.2017.10.006

[15] Vance, E.D., Prisley, S.P., Schilling, E.B., Tatum, V.L., Wigley, T.B., Lucier, A.A., Van Deusen, P.C. Environmental implications of harvesting lower-value biomass in forests. Forest Ecology and Management, 2018, Vol. 407, pp. 47-56. https:// doi.org/10.1016/j.foreco.2017.10.023

[16] Simwanda, M., Sessions, J., Boston, K., Wing, M. G., Modeling Biomass Transport on Single-Lane Forest Roads. Forest Science, 2015, Vol. 61, No 4, pp. 763-773. https://doi.org/10.5849/forsci.14-059
[17] Zamora-Cristales, R., Sessions, J. Are double trailers cost effective for transporting forest biomass on steep terrain? California Agriculture, 2015, Vol. 69, No 3, pp. 177-183. https://doi.org/10.3733/ca.v069n03p177

[18] Zamora-Cristales, R., Sessions, J., Boston, K., Murphy, G. Economic Optimization of Forest Biomass Processing and Transport in the Pacific Northwest USA. Forest Science, 2015, Vol. 61, No 2, pp. 220-234. https://doi. org/10.5849/forsci.13-158

[19] Bajec, P., Tuljak-Suban, D. Selecting a Logistics Service Provider: A Definition of Criteria that Consider the Requirements of an External Competitive Environment. Transport Problems, 2017, Vol. 12, pp. 158-168. DOI: 10.20858/ tp.2017.12.se.14.

[20] Grancay, M., Grancay, N., Drutarovska, J., Mura, L. Gravity model of trade of the Czech and Slovak Republics 1995-2012: How have determinants of trade changed. Politicka Ekonomie, 2015, Vol. 63, No 6, pp. 759-777. ISSN 0032 3233.

[21] Hajduová, Z., Andrejkovič, M., Mura, L. Utilizing experiments designed results during error identification and improvement of business processes. Acta Polytechnica Hungarica, 2014, Vol. 11, No 2, pp. 149-166. ISSN 1785-8860.

[22] Akhtari, S., Sowlati, T., Day, K. Optimal flow of regional forest biomass to a district heating system. International Journal of Energy Research, 2014, Vol. 38, No 7, pp. 954-964. https://doi.org/10.1002/er.3099

[23] Klapec, B., Tracz, W., Jianeczko, K. Optimization of the transportation of wood purchased in the State Forests units. Sylwan, 2017, Vol. 161, No 10, pp. 842 850. ISSN 0039-7660.

[24] Andersen, K., Andersson, H., Christiansen, M., Gronhaug, R., Sjamsutdinov, A Designing a maritime supply chain for distribution of wood pellets: a case study from southern Norway. Flexible Services and Manufacturing Journal, 2017, Vol. 29, No 3-4, pp. 572-600. https://doi.org/10.1007/s10696-016-9269-z

[25] Rakhmangulov, A, Sladkowski, A, Osintsev, N, Muravev, D. Green logistics: Element of the sustainable development concept. Part 1. Nase More, 2017, Vol. 64, No 3, pp. 120-126. https://doi.org/10.17818/NM/2017/3.7 